\title{
ĐÁNH GIÁ TUÂN THỦ ĐIỀU TRỊ NGOẠI TRÚ CỦA NGƯỜI BỆNH TĂNG HUYẾT ÁP BẰNG Bộ CỔNG CỤ MUAH-16
}

\section{TÓM TẮT}

Mục tiêu: Xác định mối liên quan giữa mức đô tuân thủ điều trị ngoại trú của người bệnh tăng huyết áp (THA) với đắc điểm cá nhân người bệnh. Phương pháp: Mô tả cắt ngang. Kết quả: Khảo sát 310 bênh nhân tăng huyết áp tại bệnh viện đa khoa tỉnh Bình Thuân. Điểm trung bình của thái đô tích cực đối với chăm sóc sức khỏe và dùng thuốc điêu trị tăng huyết áp là 24,5 (TB 24,5 2 2,5). Điểm trung bình của hành vi tích cực với các vấn đề sức khỏe là 22,8 (TB 22,8 \pm $3,7)$. Mức đô tích cực đối với tuân thủ điều tri ngoai trú của người bệnh THA chiếm tỷ lệ khá cao là $>75 \%$. Điểm trung bình của sư thiếu tuân thủ tăng huyết áp là 10,6 (TB 10,6 $\pm 4,7$ ) tương ứng tỷ lệ >25\%-50\% đạt mức tuân thủ thấp. Điểm trung bình của lo ngại việc dùng thuốc là 9,5 (TB 9,5 $\pm 4,6)$ tương ứng tỷ lệ 0\%-25\% đat mức tuân thủ rất thấp. Có mối liên quan giữa sự thiếu tuân thủ điều trị THA với đặc điểm dân số xã hội bậc học của người bệnh THA.Có mối liên quan giữa lo ngại việc dùng thuốc với đặc điểm dân số xã hội, bậc học của người bệnh THA. Nighiên cứu cho thấy có mối liên quan giữa thái độ tích cực đối với chăm sóc sức khỏe và dùng thuốc với các vấn đề sức khỏevà bênh đồng mắc. Kết luân: Mức đô tích cực đối với tuẩn thủ điều trị ngoại trú của người bệnh THA chiếm tỷ lệ khá cao là $>75 \%$. Có mối liên quan giữa sự thiếu tuân thủ điều trị THA với giới tính nữ; liên quan giữa hành vi tích cực với nhóm tuổi và tình trang hôn nhân của người bệnh THA vàvới tiền sử mắc bệnh khác ngoài THA. Có mối liên quan giữa thái độ tích cực chăm sóc sức khỏe và dùng thuốc và liên quan giữa hành vi tích cực với các bệnh đồng mắc.

Tư khóa: Tuẩn thủ điều trị, tăng huyết áp, bộ công cụ Muah-16

\section{SUMMARY}

ASSESSMENT OF THE OUTPATIENT TREAMENT ADHERENCE OF HYPERTENSIVE PATIENTS BY MUAH-16 TOOLKIT

Objecctives: To determine the relationship between the degree of outpatient treatment adherence to hypertensive patients with their individual characteristics. Methods: Cross-sectional Description. Results: Survey of 310 hypertensive patients at Binh Thuan general hospital. Themean score of positive attitude towards health care and antihypertensive medication use was 24.5 (mean 24.5 \pm 2.5 ). The mean score of positive behavior with

${ }^{1}$ Đại học Y Dược TP Hồ Chí Minh,

ªênh viên Đa khoa Bình Thuân

Chịu trách nhiệm chính: Vũ Trí Thanh

Email: thanh.vi@umc.edu.vn

Ngày nhận bài: 19/5/2021

Ngày phản biên khoa hoc: 10/6/2021

Ngày duyệt bài: 5/7/2021

\section{Vũ Trí Thanh ${ }^{1}$, Võ Huyền Diễm Tú ${ }^{2}$}

health problems was 22.8 (mean $22.8 \pm 3.7$ ). The degree of positivity towards outpatient adherence is quite high more than $75 \%$. The mean score of nonadherence to hypertension was 10.6 (mean $10.6 \pm$ 4.7 ), corresponding to more than $25 \%-50 \%$ low adherence. The mean score of concern about drug use was 9.5 (mean $9.5 \pm 4.6$ ), corresponding to $0 \%-25 \%$ very low adherence. There was a relationship between the lack of adherence with hypertension anxiety about taking drugs with socio-demographic characteristics and educational level. Research showed that there was a relationship between positive attitudes towards health care and medication usewith co-morbidities. Conclusions: The positive level for outpatient treatment adherence of hypertensive patients accounted for a fairly highmore than $75 \%$. There was a relationship between the lack of adherence to hypertension treatment to female patients and between positive behavior with the age group, marital status and a history of illness other than hypertension. There is an association between positive attitudes towards health care and drug use; between positive behavior and comorbidities.

Keywords: Treatment adherence, hypertension, Muah-16 toolkit

\section{I. ĐẶT VẤN ĐỀ}

Tăng huyết áp (THA) là một trong những yếu tố nguy cơ chính đối với bệnh tim mạch. Theo Tổ chức Y tế Thế giới (WHO), khoảng một tỷ người bi ảnh hưởng bởi điều này trên toàn Thế giới. Ước tính rằng sẽ có chín triệu người chết mỗi năm do THA. Điêu trị THA có thể giảm $40 \%$ nguy cơ TBMMN và $15 \%$ nguy cơ nhồi máu cơ tim. Hầu hết người bị THA không có biểu hiện triệu chứng gì và thậm chí không biết mình bị bệnh, không đươc điều trị hoặc điều trị chưa đây đủ. Biện pháp đơn giản nhất giúp kiểm soát huyết áp là tuân thủ điều trị. Việc tuân thủ điêu trị giúp kiểm soát huyết áp và giảm tối đa nguy cơ tim mạch. Vì thế chúng tôi thực hiện đề tài nghiên cứu "Đánh giá tuân thủ điều trị ngoại trú của người bệnh tăng huyêt áp bằng bộ công cụ $M U A H-16^{\prime \prime}$, tìm hiểu các lý do kém tuân thủ điêu trị của người bệnh và xây dựng các biện pháp can thiệp để tăng cường sự tuân thủ điêu trị của người bệnh THA. Mục tiêu nghiên cứu: Xác định mối liên quan giữa mức độ tuân thủ điều trị ngoại trú của người bệnh tăng huyêt áp với đặc điềm cá nhân người bệnh.

\section{II. ĐỐI TƯỢNG VÀ PHƯƠNG PHÁP NGHIÊN CỨU 2.1. Phương pháp nghiên cứu: Mô tả cắt ngang}


2.2. Đối tượng nghiên cứu: Người $\geq 40$ tuổi THA nguyên phát được chẩn đoán theo tiêu chuẩn của WHO và Bộ $Y$ tế, tăng huyết áp khi HA tâm thu $\geq 140 \mathrm{mmHg}$ và/hoặc HA tâm trương $\geq 90 \mathrm{mmHg}$.

Tiêuu chuẩn chọn mẫu: Người bệnh THA $\geq$ 40 tuổi đang được điều trị ngoại trú tại phòng khám và Khoa nội tim mạch bệnh viện tỉnh Bình Thuận trong thời gian từ tháng 03 năm 2020 đến tháng 05 năm 2020, có khả năng đọc, hiểu, nghe, nói được tiếng Việt và đồng ý tham gia nghiên cứu.

Tiêu chuẩn loại trừ: Loại trừ những trường hợp đang có thai.

2.3. Thu thập dữ liệu: Sử dụng công cụ MUAH-16 để đo lường mức độ tuân thủ điều trị của người bệnh THA. MUAH có 16 câu hỏi chia làm 4 thành phần, mỗi thành phần có 4 câu hỏi. Đánh giá theo thang đo 7 mức độ của Likert scale, phạm vi từ "hoàn toàn không đồng ý" (1 điểm) đến "hoàn toàn đồng ý" (7 điểm).

2.4. Xử lý dữ liệu: Sử dụng phần mềm SPSS 22.0 để nhập liệu. Tính trung bình và độ lệch chuẩn để xác định mức độ tuân thủ điều trị THA; Phép kiểm Independent Samples T-test, ANOVA sẽ được sử dụng để xác định mối liên quan giữa các yếu tố và mức độ tuân thủ.

\section{KẾT QUẢ NGHIÊN CứU}

Bảng 1. Đặc điểm dân số dân số xã hội của người bệnh tăng huyêt áp tham gia nghiên cứu $(n=310)$

\begin{tabular}{|c|c|c|}
\hline Đặc điếm & Tân số & Tỷ lệ \% \\
\hline Giới tính: Nữ & 154 & 49,7 \\
\hline Nam & 156 & 50,3 \\
\hline Tuối: $40-50$ & 20 & 6,5 \\
\hline $51-60$ & 85 & 27,4 \\
\hline $61-70$ & 106 & 34,2 \\
\hline$>70$ & 99 & 31,9 \\
\hline
\end{tabular}

\begin{tabular}{|c|c|c|}
\hline $\begin{array}{l}\text { Kết hôn chính thức/không } \\
\text { chính thức }\end{array}$ & 264 & 85,2 \\
\hline Góa & 46 & 14,8 \\
\hline \multicolumn{3}{|l|}{ Nghề nghiệp } \\
\hline Công nhân & 8 & 2,6 \\
\hline Nông dân & 192 & 61,9 \\
\hline Viên chức & 54 & 17,4 \\
\hline Buôn bán & 11 & 3,5 \\
\hline Hưu trí & 23 & 7,4 \\
\hline Nội trợ & 22 & 7,1 \\
\hline \multicolumn{3}{|l|}{ Trình độ học vấn } \\
\hline Tiểu học & 156 & 50,3 \\
\hline Trung học cơ sở & 74 & 23,9 \\
\hline Trung học phố thông & 12 & 3,9 \\
\hline Sơ cấp/ trung cấp/ hoc nghề & 38 & 12,3 \\
\hline Đai hoc/ cao đằng trở lên & 0 & \\
\hline
\end{tabular}

Bảng 2. Thuộc tính của thang đo đánh giá mức độ tuân thủ điều trị tăng huyết áp

\begin{tabular}{|c|c|}
\hline Đặc điếm & Alpha Cronbach \\
\hline Thang đo chung MUAH & 0,96 \\
\hline Thang đo MUAH thành phần & \\
\hline $\begin{array}{c}\text { Thái độ tích cực đối với } \\
\text { chăm sóc sức khỏe và } \\
\text { dùng thuốc }\end{array}$ & 0,84 \\
\hline Thiếu tuân thủ & 0,90 \\
\hline Lo ngại việc dùng thuốc & 0,90 \\
\hline $\begin{array}{c}\text { Hành vích cực với các } \\
\text { vấn đề sức khỏe }\end{array}$ & 0,89 \\
\hline & \\
\hline
\end{tabular}

Hình 1. Mức độ tích cực và tiêu cực đôi với tuân thủ điều trị của người bệnh THA

Bảng 3. Mối liên quan giữa tuân thủ điều trị với các đặc điểm dân số xã hội của người bệnh tăng huyết áp

\begin{tabular}{|c|c|c|c|c|c|c|c|c|c|}
\hline \multirow[t]{2}{*}{ Đặc điểm } & \multirow[t]{2}{*}{$\mathbf{N}$} & \multicolumn{2}{|c|}{$\begin{array}{c}\begin{array}{c}\text { Thái độ tích cực } \\
\text { đối với chăm sóc } \\
\text { sức khỏe và dùng } \\
\text { thuốc }\end{array} \\
\end{array}$} & \multicolumn{2}{|c|}{$\begin{array}{l}\text { Thiếu } \\
\text { tuân thủ }\end{array}$} & \multicolumn{2}{|c|}{$\begin{array}{c}\text { Lo ngại việ̂c dùng } \\
\text { thuốc }\end{array}$} & \multicolumn{2}{|c|}{$\begin{array}{c}\text { Hành vi tích cực } \\
\text { với các vấn đề sức } \\
\text { khỏe }\end{array}$} \\
\hline & & \begin{tabular}{|l|}
$T B$ \\
TBLC)
\end{tabular} & $\mathrm{p}$ & $\mathrm{TB}(\mathrm{DLC})$ & $\mathrm{p}$ & $\mathrm{TB}(\mathrm{DLC})$ & $p$ & $\mathrm{~TB}(\mathrm{DLC})$ & $p$ \\
\hline Giới tính: Nữ & 154 & $24,5(2,6)$ & 0,738 & $11,2(5,1)$ & $0,028^{*}$ & $10,1(5,0)$ & $0,011^{*}$ & $22,5(3,9)$ & 0,069 \\
\hline Nam & 156 & $24,6(2,4)$ & & $10,0(4,3)$ & & $8,8(4,1)$ & & $23,2(3,4)$ & \\
\hline Tuối: 40-50 & 20 & $24,6(2,3)$ & 0,935 & $9,5(3,9)$ & 0,501 & $9,7(5,2)$ & 0,839 & $23,5(3,8)$ & $0,048 * *$ \\
\hline $51-60$ & 85 & $24,4(2,5)$ & & $10,8(4,7)$ & & $9,7(4,8)$ & & $23,3(3,5)$ & \\
\hline $61-70$ & 106 & $24,6(2,4)$ & & $10,3(4,9)$ & & $9,1(4,4)$ & & $23,1(3,4)$ & \\
\hline$>70$ & 99 & $24,6(2,8)$ & & $11,0(4,8)$ & & $9,5(4,6)$ & & $22,0(4,0)$ & \\
\hline \multicolumn{10}{|c|}{ Tình trạng hôn nhân } \\
\hline
\end{tabular}


VIETNAM MEDICAL JOURNAL N ${ }^{0} 1$ - AUGUST - 2021

\begin{tabular}{|c|c|c|c|c|c|c|c|c|c|}
\hline $\begin{array}{l}\text { Kết hôn chính } \\
\text { thức/ không } \\
\text { chính thức }\end{array}$ & 264 & $24,5(2,5)$ & 0,624 & $10,5(4,7)$ & 0,261 & $9,5(4,6)$ & 0,994 & $23,1(3,5)$ & $0,015^{*}$ \\
\hline Góa & 46 & $24,7(2,9)$ & & $11,3(4,8)$ & & $9,5(4,9)$ & & $21,4(4,4)$ & \\
\hline \multicolumn{10}{|c|}{ Nghề nghiêp } \\
\hline Công nhân & 8 & $24,9(0,8)$ & 0,142 & $9,4(3,3)$ & $0,007 * *$ & $8,4(3,5)$ & $0,003 * *$ & $24,0(3,1)$ & $0,001 * *$ \\
\hline Nông dân & 192 & $24,5(2,7)$ & & $10,6(4,7)$ & & $9,4(4,8)$ & & $22,7(3,8)$ & \\
\hline Viên chức & 54 & $24,9(2,0)$ & & $9,8(4,5)$ & & $9,0(4,2)$ & & $23,8(3,0)$ & \\
\hline Buôn bán & 11 & $25,6(1,9)$ & & $7,3(1,5)$ & & $6,5(1,0)$ & & $25,5(1,2)$ & \\
\hline Hưu trí & 23 & $23,0(3,1)$ & & $14,1(5,4)$ & & $13,3(4,9)$ & & $20,2(3,8)$ & \\
\hline Nội trợ & 22 & $24,7(1,9)$ & & $10,6(4,9)$ & & $8,8(3,5)$ & & $22,6(3,6)$ & \\
\hline \multicolumn{10}{|c|}{ Bậc học } \\
\hline Tiếu học & 156 & $24,2(2,8)$ & 0,580 & $11,3(4,8)$ & D,035** & $10,1(4,9)$ & $0,049 * *$ & $22,0(3,9)$ & $<0,001^{* *}$ \\
\hline Trung học cơ sơ & 74 & $24,9(2,3)$ & & $9,6(4,4)$ & & $8,5(4,4)$ & & $23,7(3,4)$ & \\
\hline $\begin{array}{c}\text { Trung học phố } \\
\text { thông }\end{array}$ & 12 & $25,3(1,5)$ & & $8,8(3,1)$ & & $7,7(3,1)$ & & $25,0(2,9)$ & \\
\hline $\begin{array}{l}\text { Sơ cấp/ trung } \\
\text { cấp/ học nghề }\end{array}$ & 38 & $24,9(2,0)$ & & $9,8(4,7)$ & & $8,7(3,7)$ & & $23,9(3,1)$ & \\
\hline $\begin{array}{l}\text { Đaai học/ cao } \\
\text { đắng trở lên }\end{array}$ & 30 & $24,8(2,2)$ & & $11,2(5,3)$ & & $10,3(4,8)$ & & $22,8(3,0)$ & \\
\hline
\end{tabular}

(* Kiếm định $\mathrm{t}$, ** kiếm định ANOVA) tăng huyết áp

\begin{tabular}{|c|c|c|c|c|c|c|c|c|c|}
\hline \multirow[t]{2}{*}{ Đặc điểm } & \multirow[t]{2}{*}{$\mathbf{N}$} & \multicolumn{2}{|c|}{$\begin{array}{c}\text { Thái độ tích cực } \\
\text { đối với chăm sóc } \\
\text { sức khỏe và } \\
\text { dùng thuốc }\end{array}$} & \multicolumn{2}{|c|}{ Thiếu tuân thủ } & \multicolumn{2}{|c|}{$\begin{array}{c}\text { Lo ngại việc dùng } \\
\text { thuô̂c }\end{array}$} & \multicolumn{2}{|c|}{$\begin{array}{l}\text { Hành vi tích cực } \\
\text { với các vấn đề } \\
\text { sức khỏe }\end{array}$} \\
\hline & & TB (ĐLC) & $\mathrm{p}$ & TB (ĐLC) & & TB (ĐLC) & $\mathrm{p}$ & TB (ĐLC) & $\mathrm{p}$ \\
\hline \multicolumn{10}{|c|}{ Mắc bệnh khác } \\
\hline Có & 303 & $24,6(2,5)$ & 0,052 & $10,4(4,6)$ & $<0,001^{*}$ & 9,3 & $<0,00$ & 22,9 & $0,013^{*}$ \\
\hline Không & 7 & $22,7(3,0)$ & & $18,3(4,1)$ & & $15,4(3,6)$ & & $19,4($ & \\
\hline \multicolumn{10}{|c|}{ Số bệnh đồng mằc } \\
\hline 0 & 7 & $22,7(3,0)$ & $0,007 * *$ & $18,3(4,1)$ & $<0,001^{* *}$ & 15,4 & k* & ,4) & $0,001^{2}$ \\
\hline 1 & 275 & $24,7(2,4)$ & & $10,2(4,5)$ & & $9,1(4,4)$ & & $23,1(3,6)$ & \\
\hline 2 & 28 & $23,5(3,0)$ & & $12,4(4,9)$ & & $11,1(5,6)$ & & $21,1(3,9)$ & \\
\hline \multicolumn{10}{|c|}{ Thời gian măc THA (năm) } \\
\hline & 118 & $24,1(2,5)$ & $0,004 * *$ & $11,0(4,8)$ & 0,163 & $10,2(5,0)$ & $0,014^{* *}$ & $22,9(3,7)$ & 0,906 \\
\hline $6-10$ & 128 & $24,5(2,6)$ & & $10,6(4,9)$ & & $9,6(4,7)$ & & $22,9(3,6)$ & \\
\hline$>10$ & 64 & $25,4(2,1)$ & & $9,6(4,1)$ & & $8,0(3,4)$ & & $22,7(3,9)$ & \\
\hline \multicolumn{10}{|c|}{ Giáo duc sức khỏe tuân thủ điều trị THA } \\
\hline Có & 26 & $22,0(2,7)$ & $<0,001^{*}$ & $15,4(4,9)$ & $<0,001^{*}$ & $15,1(4,9)$ & $<0,001^{*}$ & $(4,1)$ & $<0,001^{*}$ \\
\hline Không & 284 & $24,8(2,4)$ & & $10,1(4,5)$ & & $8,9(4,2)$ & & $23,1(3,5)$ & \\
\hline \multicolumn{10}{|c|}{ Đánh giá huyết áp hiện tại } \\
\hline Không tốt & 90 & $24,1(3,1)$ & $0,018^{* *}$ & $11,4(5,2)$ & $<0,001^{* *}$ & $10,5(5,5)$ & \begin{tabular}{|l|}
$0,005^{* *}$ \\
\end{tabular} & $(4,1)$ & $\left\langle 0,001^{*}\right\rangle$ \\
\hline Không biết & 151 & $24,4(2,4)$ & & $11,2(5,0)$ & & $9,9(4,6)$ & & $22,5(3,7)$ & \\
\hline Tốt & 69 & $25,4(1,7)$ & & $8,1(2,1)$ & & $7,2(2,1)$ & & $25,1(1,9)$ & \\
\hline \multicolumn{10}{|c|}{ Huyết áp tuần vừa qua $\geq 140 / 90(\mathrm{mmHg})$} \\
\hline Có & 246 & $24,4(2,6)$ & $0,012^{*}$ & $10,9(4,8)$ & $0,016^{*}$ & $9,9(4,8)$ & $<0,001^{*}$ & $(3,8)$ & $0,004 *$ \\
\hline Không & 64 & $25,2(2,0)$ & & $9,3(4,2)$ & & $8,0(3,3)$ & & $23,9(3,0)$ & \\
\hline \multicolumn{10}{|c|}{ Huyết áp hiện tại $\geq 140 / 90(\mathrm{mmHg})$} \\
\hline Có & 117 & & 0,994 & $11,2(5,1)$ & 0,083 & $9,8(4,8)$ & 0,375 & $3,8)$ & $0,028^{*}$ \\
\hline Không & 193 & $24,5(2,4)$ & & $10,2(4,5)$ & & $9,3(4,5)$ & & $23,2(3,6)$ & \\
\hline
\end{tabular}

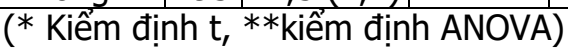




\section{BÀN LUÂ̂N}

Kết quả nghiên cứu cho thấy mức độ tích cực đối với tuân thủ điều trị ngoại trú của người bệnh THA chiếm tỷ lệ khá cao là $>75 \%$. Kết quả nghiên cứu này tương đồng với nghiên cứu của Michel Burnier cho biết mức cắt $80 \%$ được đánh giá là tuân thủ tốt [7]. Kết quả này cao hơn so với nghiên cứu của Phạm Thành Đạt cho biết tỷ lệ người bệnh THA có tập thể dục là $44 \%$, hạn chế ăn mặn là 48,6\%, ăn chất béo là 35,5\% [1]; Kết quả nghiên cứu của Lữ Thị Khuê Tú cho biết tỷ lệ người bệnh THA tập thể dục là 40,2\% [4].

Đánh giá mức độ tiêu cực đối với việc tuân thủ điều trị của người bệnh THA có 2 thành phần bao gồm: thiếu tuân thủ và lo ngại việc dùng thuốc. Điểm trung bình của sự thiếu tuân thủ là 10,6 (TB 10,6 $\pm 4,7$ ) tương ứng tỷ lệ >25\%$50 \%$ đạt mức tuân thủ thấp. Điểm trung bình của lo ngại việc dùng thuốc là 9,5 (TB 9,5 $\pm 4,6$ ) tương ứng tỷ lệ $0 \%-25 \%$ đạt mức tuân thủ rất thấp. Kết quả này cao hơn so với nghiên cứu của Nguyễn Thị Thu Hằng: tỷ lệ người bênh thường xuyên quên uống thuốc là $12,25 \%$, người bệnh quên mang thuốc khi đi du lịch là 3,76\%, người bệnh thường xuyên gặp khó khăn để nhớ uống tất cả các loại thuốc là 2,76\% [2]. Kết quả này thấp hơn so với nghiên cứu của Lữ Thị Khuê Tú: tỷ lệ người bênh đã từng quên uống thuốc là 63,5\% [4]. Nghiên cứu của Phạm Thành Đạt cho biết có $50,2 \%$ người bệnh đã từng quên uống thuốc, $66,7 \%$ người bệnh đã từng quên uống thuốc trong hai tuần qua, 70\% người bệnh đi xa nhà nhiêu ngày quên mang theo thuốc [1]. Nghiên cứu của Bùi Thị Mai Tranh cho biết người bệnh sợ uống nhiều thuốc chiếm tỷ lệ $31 \%$ [3]. Theo kết quả nghiên cứu của Michel Burnier cho biết việc phải uống nhiều thuốc hàng ngày và thuốc gây nhiều tác dụng phụ sẽ làm giảm sự tuân thủ điều trị [7]

Có mối liên quan giữa sự thiếu tuân thủ điều trị THA với đặc điểm bậc học của người bệnh THA, điểm trung bình nhóm người bệnh có bậc học tiểu học cao nhất. Có mối liên quan giữa ì ngại việc dùng thuốc với bậc học của người bệnh THA, điểm trung bình nhóm bậc tiểu học thấp hơn nhóm đại học/cao đẳng trở lên và cao hơn nhóm sơ cấp/ trung cấp/ học nghề, trung học cơ sở và trung học phổ thông. Kết quả này khác biệt với nghiên cứu ở Cameroon cho thấy tình trạng giáo dục không liên quan đến sự tuân thủ [5] nhưng phù hợp với nghiên cứu của Manal Ibrahim Hanafi Mahmoud cho biết trình độ văn hóa, tình trạng công việc ảnh hưởng đến mức độ tuân thủ [6]. Nghiên cứu tại Ethiopia cho biết trình độ thấp cũng là yếu tố gây thiếu tuân thủ điều trị, lo ngại khi dùng thuốc [8].

Nghiên cứu cho thấy có mối liên quan giữa thái độ tích cực đối với chăm sóc sức khỏe và dùng thuốc; hành vi tích cực với các vấn đề sức khỏevới số bệnh đồng mắc. Điểm trung bình của nhóm không có bệnh đồng mắc thấp hơn so với nhóm có 2 bệnh đồng mắc và nhóm có 1 bệnh đồng mắc. Có mối liên quan giữa sự thiếu tuân thủ điều trị THA; lo ngại việc dùng thuốc với số bệnh đồng mắc. Kết quả này phù hợp với nghiên cứu của Michel Burnier [7].Nghiên cứu của Manal Ibrahim Hanafi Mahmoud Đai học Taibah cho biết $83 \%$ người bệnh mắc thêm các bệnh kèm theo tuân thủ điều trị kém [6].

\section{KẾT LUÂ̂N}

Mức độ tích cực đối với tuân thủ điều trị ngoại trú của người bệnh THA chiếm tỷ lệ khá cao là $>75 \%$. Có mối liên quan giữa sự thiếu tuân thủ điều trị THA và lo ngại việc dùng thuốc với người bệnh THA là giới nữ. Có mối liên quan giữa hành vi tích cực với các vấn đề sức khỏe với nhóm tuổi và tình trạng hôn nhân của người bệnh THA, trong đó, nhóm tuổi từ 40-50 cao nhất và nhóm người bệnh kết hôn chính thức/không chính thức cao hơn nhóm góa. Có mối liên quan giữa sự thiếu tuân thủ điều trị THA; lo ngại việc dùng thuốc; hành vi tích cực với các vấn đề sức khỏevới tiền sử mắc bệnh khác ngoài THA. Có mối liên quan giữa thái độ tích cực đối với chăm sóc sức khỏe và dùng thuốc; giữa hành vi tích cực với các vấn đề sức khỏe và bệnh đồng mắc.

\section{TÀI LIỆ THAM KHẢO}

1. Phạm Thành Đạt (2019), "Tỷ lê tuân thủ điều trị và một số yếu tố liên quan ở bệnh nhân tăng huyết áp người dân tộc Khmer tại trung tâm y tế huyện Châu Thành, Tỉnh Tiền Giang", Khóa luận tốt nighiệp bác sĩ y học dự phòng, Đại học Y Dược Tp. HCMM.

2. Nguyển Thu Hằng, Nguyễn Thị Thùy Dương, Hố Thị Dung, et al. (2018), "Khảo sát tình hinh tuân thủ trong sử dụng thuốc trên bệnh nhân tăng huyết áp điều trị ngoại trú tại bệnh viện đa khoa thành phố Vinh năm 2018", Tạp chí khoa học công nghệ Nghệ An, tr. 35-39.

3. Bùi Thị Maì Tranh, Nguyễn Minh Đức, Nguyển Đố Nguyên (2012), "Sự tuân thủ dùng thuốc hạ áp trên bệnh nhân cao tuổi tăng huyết áp", Y học TP. Hồ Chí Minh, 16 (số 4).

4. Lữ Thị Khuê Tú (2019), "Tỷ lệ tuân thủ điều trị tăng huyết áp và các yếu tố liên quan ở bệnh nhân tăng huyết áp tại phường 8, Quận 6 TP. HCM", Đại hoc Y Dược TP. HCM.

5. Akoko. B. M., Fon. P. N., Ngu. R. C., et al. (2017), "Knowledge of Hypertension and Compliance with Therapy Among Hypertensive 
Patients in the Bamenda Health District of Cameroon: A Cross-sectional Study", Cardiology and Therapy, 6, pp. 53-67.

6. Ibrahim M., Mahmoud H. (2012), "Compliance with treatment of patients with hypertension in Almadinah Almunawwarah: A communitybased study", Journal of Taibah University Medical Sciences, 7 (2), pp. 92-98.
7. Michel B., Brent M E. (2019), "Adherence in Hypertension; A Review of Prevalence, Risk Factor, Impact, and Management", Circulation Research, 124 (7).

8. Niriayo Y. L., Ibrahim S., Kassa T. D., et al. (2019), "Practice and predictors of self-care behaviors among ambulatory patients with hypertension in Ethiopia", PLoS One, 14 (6), pp. e0218947.

\section{KIỂU HÌNH KHÒ KHÈ Ở TRẺ EM DƯớI 5 TUỔI TẠI QUẢNG NINH}

\section{TÓM TẮT}

Khò khè là triêu chứng thường găp ở trẻ em. Kiểu hình khò khè khác nhau gây nên bởi nguyên nhân khác nhau. Đối tượng và phương pháp: Nghiên cứu được tiến hành tại khoa Nhi bệnh viện Bãi Cháy và khoa nội nhi bệnh viện Sản Nhi Quảng Ninh trên 164 bệnh nhân dưới 5 tuổi vào viện vì khò khè trong giai đoạn từ 01/07/2020 đến 30/06/2021. Mục tiêu: Mô tả kiểu hình khò khè ở trẻ em dưới 5 tuổi tại tỉnh Quảng Ninh. Kết quả: Tỷ lệ trẻ khởi phát khò khè sớm (trước 12 tháng tuổi), trung gian (từ 12 đến 24 tháng tuổi), muộn (sau 24 tháng đến 60 tháng) lần lượt là $77,4 \% ; 17,7 \%$ và $4,9 \%$. Trong đó, nhóm trẻ dưới 12 tháng chiếm tỷ lệ 57,9\%. Có 54,9\% trẻ dưới 5 tuổi có ít nhất 2 đợt khò khè. Khò khè từng đợt do virus hay gặp ở nhóm dưới 12 tháng, chiếm tỷ lệ $46 \%$, khò khè nhiêu yếu tố khởi phát gặp ở nhóm trên 12 tháng chiếm tỷ lệ $80 \%$. Có mối liên quan giữa số đợt khò khè với tiên sử di ứng của bản thân và gia đình, tiền sử tiếp xúc với khói thuốc lá $(p<0,05)$. Nguyên nhân khò khè hay gặp nhất ở nhóm dưới 12 tháng là viêm tiểu phế quản chiếm tỷ lệ $74,7 \%$. Nhóm 25 đến 60 tháng nguyên nhân hay gặp là hen phế quản chiếm tỷ lệ 87,5\%. Kết luận: Kiêu hình khò khè khác nhau trong các nhóm bênh lý khác nhau

Từ khóa: kiểu hình khò khè, trẻ em

\section{SUMMARY}

\section{WHEEZING PHENOTYPES IN CHILDREN UNDER 5 YEARS OF AGE IN QUANG NINH PROVINCE}

Wheezing is a common symptom which is often seen in children. The different wheezing phenotypes are caused by a variety of diseases. Materials and methods: This study was conducted in 164 children under 5 years of ages hospitalized due to wheezing at the Pediatric Department of Bai Chay Hospital and Internal Medicine Pediatrics Department of Quang Ninh Obstetrics and Children's Hospital, from July $1^{\text {st }}$,

\footnotetext{
1,2Bênh viện Đa khoa Bãi cháy

${ }^{2}$ Trường Đại học Y Hà Nội

Chịu trách nhiệm chính: Nguyễn Thị Huyền

Email: drnguyenhuyen82@gmail.com

Ngày nhân bài: 3.5.2021

Ngày phản biện khoa học: 30.6.2021

Ngày duyệt bài: 6.7.2021
}

\section{Nguyễn Thị Huyền ${ }^{1,2}$, Nguyễn Thị Diệu Thúy ${ }^{2}$}

2020 to June $30^{\text {th }}, 2021$. Objectives: To describe the wheezing phenotypes of children under 5 years of age in Quang Ninh province. Results: The prevalence of early onset of wheeze (before 12 months of age), intermediate (from 12 to 24 months of age), and late (after 24 months to 60 months) was $77.4 \% ; 17.7 \%$ and $4.9 \%$ respectively. $57.9 \%$ of wheezing ocured in children under 12 month. In addition, $54.9 \%$ of children under 5 ages had at least 2 episodes of wheeze. Episodic viral wheeze was common in the children under 12 month group, accounting for $46 \%$ wheares multitrigger wheeze was common in children over 12 month group, accounting for $80 \%$. There were a statistically associated between the frequency of wheezing and personal and family history of allergies, second hand smoke exposure in children with wheezing $(p<0.05)$. The most common cause of wheezing in the group under 12 month was bronchiolitis, accounted for $74.7 \%$. In the group of 25 to 60 months, the common cause was asthma, accounted for $87.5 \%$. Conclusion: Wheezing phenotypes are different in different diseases.

Keywords: Wheezing phenotype, children

\section{I. ĐẶT VẤN ĐỀ}

Khò khè là triệu chứng thường gặp ở trẻ em. Gần $50 \%$ trẻ em bị khò khè trong năm đâu đời, $20 \%$ sẽ tiếp tục bi triệu chứng khò khè trong những năm tiếp theo ${ }^{1}$. Khò khè ít khi biểu hiện đơn độc mà thường kết hợp với các triệu chứng hô hấp khác như ho, tức ngực, thở nhanh và/hoặc khó thở... tùy thuộc vào nguyên nhân gây ra khò khè. Nhiêu bố mẹ khi thây trẻ khò khè tái diễn thường nghĩ rằng đó là triệu chứng của hen phế quản. Tuy nhiên, tình trạng khò khè có thể được cải thiện và biến mất theo thời gian ở nhiều trẻ em. Vì vậy, xác định kiểu hình khò khè đã được nghiên cứu nhằm phân loại và tiên đoán khả năng phát triển thành bệnh hen phế quản trong tương lai². Mặc dù khò khè là triệu chứng thường gặp ở trẻ nhỏ, hay gây lo lắng cho gia đình bệnh nhân và thây thuốc nhưng cách tiếp cận với trẻ bị khò khè là một thách thức đối với các nhà lâm sàng, đặc biệt là các thây thuốc nhi khoa từ việc chẩn đoán tới điêu trị và tiên lượng. Thêm nữa, một số thăm dò nhằm tìm 